\title{
YIELD MAPPING, SOIL FERTILITY AND TREE GAPS IN AN ORANGE ORCHARD ${ }^{1}$
}

\author{
JOSÉ PAULO MOLIN² ${ }^{2}$ ANDRÉ FREITAS COLAÇO ${ }^{3}$, \\ EDUARDO FERMINO CARLOS ${ }^{4}$, DIRCEU DE MATTOS JUNIOR 5
}

ABSTRACT- The current high competition on Citrus industry demands from growers new management technologies for superior efficiency and sustainability. In this context, precision agriculture (PA) has developed techniques based on yield mapping and management systems that recognize field spatial variability, which contribute to increase profitability of commercial crops. Because spatial variability is often not perceived the orange orchards are still managed as uniform and adoption of PA technology on citrus farms is low. Thus, the objective of the present study was to characterize the spatial variability of three factors: fruit yield, soil fertility and occurrence of plant gaps caused by either citrus blight or huanglongbing (HLB) in a commercial Valencia orchard in Brotas, São Paulo State, Brazil. Data from volume, geographic coordinates and representative area of the bags used on harvest were recorded to generate yield points that were then interpolated to produce the yield map. Soil chemical characteristics were studied by analyzing samples collected along planting rows and inter-rows in 24 points distributed in the field. A map of density of tree gaps was produced by georeferencing individual gaps and later by counting the number of gaps within $500 \mathrm{~m}^{2}$ cells. Data were submitted to statistical and geostatistical analyses. A t test was used to compare means of soil chemical characteristics between sampling regions. High variation on yield and density of tree gaps was observed from the maps. It was also demonstrated overlapping regions of high density of plant absence and low fruit yield. Soil fertility varied depending on the sampling region in the orchard. The spatial variability found on yield, soil fertility and on disease occurrence demonstrated the importance to adopt site specific nutrient management and disease control as tools to guarantee efficiency of fruit production.

Index terms: Precision agriculture, spatial variability, citrus blight, huanglongbing (HLB).

\section{MAPEAMENTO DA PRODUTIVIDADE, FERTILIDADE DO SOLO E FALHAS DE PLANTAS EM POMAR DE LARANJEIRAS}

RESUMO - A atual competitividade existente no setor citrícola demanda dos produtores novas estratégias de manejo para aumento de eficiência e sustentabilidade. Nesse sentido, a agricultura de precisão (AP) tem desenvolvido técnicas baseadas no mapeamento de produtividade e sistemas de manejos que reconheçam a variabilidade espacial existente no campo, o que contribui para aumentar a lucratividade de pomares comerciais. Como a variabilidade espacial normalmente não é visualizada, os pomares ainda são manejados como uniformes, e a adoção das tecnologias de AP nas fazendas citrícolas é baixa. Dessa forma, o objetivo do trabalho foi carcaterizar a variabilidade espacial de três fatores: produtividade de frutos, fertilidade do solo e ocorrência de falhas de plantas causadas pelo declínio dos citros e pelo (HLB), em um talhão comercial de citros em Brotas-SP. Dados de volume, coordenadas geográficas e área de representação dos sacolões utilizados na colheita foram registrados para gerar pontos de produtividade, que foram interpolados para produzir o mapa de produtividade. As características químicas do solo foram estudadas por meio de análises de amostras coletadas ao longo das linhas de plantio e no centro das entrelinhas em 24 pontos distribuídos no talhão. Um mapa de densidade de falhas de plantas foi realizado por meio do georreferenciamento das falhas e da posterior contagem do número de falhas em células de $500 \mathrm{~m}^{2}$. Os dados foram submetidos a análises estatísticas e geoestatísticas. Utilizou-se o teste t para comparação de médias das características químicas do solo entre as regiões de amostragem. A partir dos mapas realizados, observou-se grande variação de produtividade e de densidade de falhas. Eles também mostraram manchas sobrepostas de alta densidade de falhas de plantas e baixa produtividade de frutos. A fertilidade do solo nas regiões amostradas mostrou-se significativamente diferente. A variabilidade espacial encontrada na produtividade, na fertilidade do solo e na ocorrência de doenças demonstrou a importância do manejo localizado nutricional e fitossanitário como ferramentas para garantir eficiência na produção de frutas.

Termos de indexação: Agricultura de precisão, variabilidade espacial, declínio, huanglongbing (HLB).

${ }^{1}$ (Trabalho 076-12). Recebido em: 31-01-2012. Aceito para publicação em: 25-07-2012.

${ }^{2}$ Associate Prof. at Biosystem Engineering Department at "Luiz de Queiroz" College of Agriculture, University of São Paulo. Av. Pádua Dias, 11, 13418-900, Piracicaba-SP, Brazil. E-mail: jpmolin@usp.br

${ }^{3}$ Graduate Student of Agricultural Engineering System Program at "Luiz de Queiroz" College of Agriculture, University of São Paulo. Av. Pádua Dias, 11, 13418-900, Piracicaba-SP, Brazil. E-mail: andre.colaco@usp.br

${ }^{4}$ Researcher at Agronomic Institute of Paraná. Rod. Celso Garcia Cid, km 375, C.P 481, 86047-902, Londrina-PR, Brazil. E-mail: efcarlos@iapar.br

5Centro de Citricultura Sylvio Moreira (IAC), Rod. Anhanguera, km 158, CEP 13490-000 - Cordeirópolis - SP, Brasil. E-mail: ddm@ centrodecitricultura.br 


\section{INTRODUCTION}

Oranges represent the main citrus species grown throughout the world and an outstanding commodity in the Brazilian and the United States agricultural commerce, two of the major world producing countries. According to the Food and Agriculture Organization (FAO, 2010) Brazil accounts for the production of 19.1 million tons cultivated on approximately 840 thousand ha, followed by about 7.4 million tons in the United States in an area of 260 thousand ha.

Demand for research and new management techniques are increasing because of the great competition and need to optimize production costs. Among the new technologies available for citrus production we find the precision agriculture (PA), which aims to manage agricultural systems considering their spatial variability regarding soil and plant characteristics that are responsible for fruit yield, like physical and chemical soil attributes and plant nutrition.

The main procedure for dealing with spatial variability is the site specific intervention, e.g. in citrus orchards, it is possible to apply different quantities of fertilizers to individual trees, as long as the application equipment adjusts to rapid rate changes (SCHUMANN et al., 2006). However, for a PA managed system to be successful, other tools are very important, including yield maps, that show the yield irregularities of the orchard. They also represent the complete information of the crop response to the management strategies adopted. Whitney et al. (1999), in a pioneer project with citrus, highlighted the importance of developing fruit yield maps and including other techniques such as variable rate of fertilizers and agrochemical application for the correct adoption of PA practices.

To produce fruit yield maps, Farias et al. (2003) and Parise and Vettorazzi (2005) proposed methods based on sampling of orchard production and further processing of geostatistical analysis to create surface maps by interpolation. Also, given the relationship between canopy volume and citrus yield (QUAGGIO et al., 2004), the potential of ultrasonic sensors to measure tree canopies and produce yield maps is verified (ZAMAN et al., 2006). Okamoto and Lee (2009) used an innovative method for detailed survey of citrus yield. The number of fruits on the trees was counted automatically using images captured by a terrestrial optical sensor. This type of equipment can be used in harvest prediction and yield mapping.
The methods quoted are very effective to show spatial variability of yield with significant details. However, they are not adapted to the daily productive reality of citrus farms. Thus, some authors have created simple methods that meet the needs of citrus growers. Schueller et al. (1999) and Tumbo et al. (2002) generated yield maps of Florida's (USA) orchards by georeferencing fruit containers used on hand harvest. In Brazil, Molin and Mascharin (2007) used a similar procedure, with adaptations to the local harvest conditions. These methods stand out for their adaptability to hand harvesting, easiness and low cost to obtain data.

In addition to yield maps, development of PA techniques in citrus orchards has also focused the spatial variability existing on soil and its influence on crop performance. According to Zaman and Schumann (2006), soil mapping showed to be essential for delimiting management zones in a study conducted on a citrus orchard in Florida, because its physical and chemical characteristics are highly related to the field spatial variability. Oliveira et al. (2009) and Siqueira et al. (2010) also mapped soil chemical characteristics showing their spatial variability and their importance on the orchard production and fruit quality.

Plant health is also of primary relevance for citrus orchard production, which can also be managed using PA techniques (MARUYAMA et al., 2006; SANKARAM et al., 2010). However, the spatial distribution of very important diseases, such as citrus blight and huanglongbing, has not yet been perceived. Thus it is necessary to use more sophisticated techniques that show their occurrence in map formats.

Although innovative PA technologies have been successfully developed, widespread adoption is slow. Lamb et al. (2007) explain that this is caused by a large knowledge gap between developers and users. Isgin et al. (2008) showed that farmer's age, financial status, farm's size and soils variability within fields can affect decision of farmers towards PA adoption. In Florida's citrus farms Sevier and Lee (2004) found that variability of the grove is an important factor that affects PA adoption in orange orchards. In many cases, because spatial variability is not perceived, commercial orchards are still managed as uniform.

The present study aimed to characterize the spatial variability of three agronomic features on a commercial orange orchard: fruit yield, soil fertility and disease occurrence in the field, as well as to verify the feasibility of mapping techniques for precision agriculture purposes. 


\section{MATERIAL AND METHODS}

A commercial 12-years-old orchard of Valencia orange trees [Citrus sinensis (L.) Osbeck] planted at $3.5 \times 7.5 \mathrm{~m}$, in Brotas, state of São Paulo, Brazil, with a total area of 26 ha was used in this the study.

Fruits were harvested at maturity by hand and placed into "big-bags" located in the center of four plant rows. A lift carried the bags into a truck that removed the harvested product from the field. Quantity of fruit in each bag was estimated by a harvest team leader by using a ruler graduated in equivalents of $27.2 \mathrm{~kg}$ boxes. To verify the data, 293 bags were weighed using a winch attached to a tractor and a load cell model LU-2TE (Kyowa Electronic Instruments Ltda ${ }$, Toquio, Japan).

The method described by Molin and Mascharin (2007) was used to generate the yield map, which was based on georeferencing of bags and on yield calculation on these points. To calculate yield it was needed the fruit mass in each bag and the area that it represented in the field. After interpolation the yield point $\left(\mathrm{t} \mathrm{ha}^{-1}\right)$ formed the surface of the yield map.

The GPS receiver AgGPS 132 (Trimble Navigation Limited ${ }^{\circledR}$ Sunnyvale, CA, USA) connected to a hand computer and the navigation software Farm Site Mate (Farm Works Software ${ }^{\circledR}$, Hamilton, IN, USA) was used to georeference the bags. The bag representative area was obtained by multiplying the harvest band width $(30 \mathrm{~m})$ by the half distance between neighboring points. For this, geographic coordinates were converted to metric coordinates (UTM) so that distances among bags could be calculated using the Pythagoras theorem.

To map spatial distribution of disease in the field the tree gaps caused by eradication of plants infected with either citrus blight or HLB diseases was georeferenced by scouting plant rows and marking a point for each gap found, using the navigation GPS eTrex (Garmin ${ }^{\circledR}$ Olathe, KS, USA). To generate this map, density of tree gaps was calculated for 543 cells of 0.05 ha distributed in the field. The number of gaps within each cell was counted using the ArcGIS 9.2 software (ESRI ${ }^{\circledR}$ Redlands, CA, USA) and linked to a coordinate generated in the center of each cell which allowed interpolation to create a gap density map.

The soil fertility maps were produced by collecting soil samples using an auger-type probe in the $0-20 \mathrm{~cm}$ depth layer in 24 points distributed in the field according to a sample grid of approximately one sample per hectare. The sample grid was previously set out with help of the GPS Trackmaker PRO 3.4 software (GPS Trackmaker ${ }^{\circledR}$, Belo Horizonte, MG, Brazil). Samples were taken from two regions in the citrus orchard: along the planting rows, within a band of $1.5 \mathrm{~m}$ wide, where fertilizers are applied adjacent to the tree canopy projection in the ground, and in the middle of the inter-rows. So, two samples were collected at each point of the grid resulting in a total of 48 samples, each one obtained by 10 sub-samples. Samples were sent to a service provider laboratory where chemical analyses were carried out according to methods described by Raij et al. (2001).

Data collected were submitted to descriptive statistics, and the $t$ test for paired means was used for soil chemical analysis results between the two sampling regions using the Microsoft Excel 2007 software (Microsoft Corporation ${ }^{\circledR}$, Redmond, WA, USA).

A geostatistical analysis was also performed with yield points, tree gap density and chemical attributes of the soil using the VESPER 1.6 software (University of Sydney, Sydney, NSW, AU) to obtain semivariograms and their parameters - nugget effect $(\mathrm{C} 0)$, sill $(\mathrm{C} 1)$ and range (A1). Semivariograms were adjusted to the model that presented the greatest coefficient of determination $\left(\mathrm{r}^{2}\right)$ among exponential, spherical, Gaussian and linear models. Map surfaces were generated on Surfer 8.0 software (Golden Software ${ }^{\circledR}$, Golden, CO, USA) by kriging interpolation. When spatial dependency was not verified, inverse distance was used as the interpolation method.

In order to analyze the influence of tree gaps on yield, these two factors were correlated using the values generated by interpolations. A linear function, coefficient of determination, coefficient of correlation and its significance on the hypothesis test were obtained between the two parameters.

\section{RESULTS AND DISCUSSION}

The weight of bags determined by the load cell and by the harvest team leader survey showed little difference between the two methods assessed $(<2 \%)$ (Table 1) and a high coefficient of determination $\left(\mathrm{R}^{2}=0.82\right.$; Prob. $\left.<0.05\right)$ (Figure 1). This fact allowed the use of only the harvest team leader data and consequently the subsequent bags did not need to be weighed during the development of the study. This difference was co-validated with results of a study conducted under the same harvest conditions by Molin and Mascharin (2007). Using a load cell, they found errors of $3.4 \%$ and $3.9 \%$ on bag weight estimative, in two harvest teams.

The georeferencing of bags resulted on 947 yield points with a mean fruit production of $25.56 \mathrm{t}$ $\mathrm{ha}^{-1}$. Yield ranged from 2.58 to $154.02 \mathrm{tha}^{-1}$ (Table 2). This wide amplitude, along with a high standard 
deviation shows a high variation on the data and the magnitude of fruit yield variability.

According to the method used to calculate plant gap density, 543 points were created with the number of gaps ha-1 information. They presented a mean value of 47.76 gaps $^{-1} a^{-1}$, that is, $12.53 \%$ the total of 380 plant ha $^{-1}$ and ranged from no gaps to 225.56 gaps ha $^{-1}$ (59.21\%) (Table 2). A total of 1,251 gaps were measured throughout the orchard.

Results obtained from soil sampling (Table 2) showed a great variation for each soil chemical attribute. Phosphorus $(\mathrm{P})$, potassium $(\mathrm{K})$, calcium $(\mathrm{Ca})$ and magnesium $(\mathrm{Mg})$ that are elements intensively managed trough fertilization, presented coefficient of variation raging from 16.29 to $108.21 \%$ showing spatial variability among the 24 point samples. The high variability found on soil chemical attributes suggests that variable rate management is an appropriate technique to deal with spatial variation of fertility. Mapping soil attributes previously to the orchards implementation could avoid great soil spatial variability within a field.

Also, there was significant difference among the sample removal regions for the chemical soil attributes analyzed, except for soil organic matter. Greater concentrations of $\mathrm{P}, \mathrm{K}$ and aluminum $(\mathrm{Al})$ were obtained in the canopy projection of the trees. $\mathrm{Ca}$ and $\mathrm{Mg}$ contents were greater in the rows center. The manner in which soil corrective products and fertilizers are applied is one of the factors responsible for the differences in elements concentration noticed on different sampling regions. Granular fertilizers, that are normally the N, P and K sources used in fertilization, tend to deposit closer to the plants because they have greater kinetic energy during application. On the other hand, $\mathrm{Ca}$ and $\mathrm{Mg}$ are supplied mainly by applying lime that does not reach the planting line entirely, leading to lower base saturation on this area. Besides the distribution pattern of lime and fertilizers, nitrogen dissolution, nitrification and the plants absorptions lead to greater acidification in the planting line (QUAGGIO et al., 1992; CANTARELLA et al., 2003).

Regarding geostatistical analysis, the adjusted models that presented the greatest coefficient of determination among tested models were exponential and spherical (Table 3). Yield points, represented by georeferenced bags, presented a low spatial dependency, because semi-variance did not increase significantly together with the distance among the pairs of points analyzed (Figure 2), resulting in $69 \%$ randomness among points (Table 3). A similar fact occurred in the study by Molin and Mascharin (2007), who obtained a pure nugget effect on the yield semivariogram in a citrus orchard. The authors used the same system of data survey on the field and emphasized that such geostatistical performance occurred because there were full and partially full bags close to each other. The same situation was reported in the present study.

For gap density data, good adjustment was obtained using the exponential model, with a 0.94 coefficient of determination $\left(\mathrm{R}^{2}\right)$. Randomness ratio was $49 \%$ illustrating significant increase in semi-variance with increase in distance among the pairs analyzed. Spatial dependence was $153.5 \mathrm{~m}$ representing the radius within which values had similarity, demonstrating the aggregated performance of gaps. Leal et al. (2010) also noticed aggregate distribution of HLB using geostatistical analyses. They found a radius of aggregation between $300 \mathrm{~m}$ and $560 \mathrm{~m}$.

This aggregated pattern was no surprise regarding citrus blight because this anomaly, of still unknown pathogen, can be transmitted experimentally by root grafting (TUCKER et al., 1984). In the field it is quite probable that natural contact among close plant roots produces the same effect, allowing the localized dissemination of the disease (CARLOS et al., 2000). On HLB, there is an insect vector ( $D i$ aphorina citri) that carries the bacteria (Candidatus Liberibacter spp.) and inoculates it in the plant (BOVÉ, 2006). The spatial distribution of this insect is also characterized by aggregation (COSTA et al., 2010). Besides, a border effect is observed, where the disease is present in larger proportions when close to contaminated orchards that serve as sources of disease (LEAL et al., 2010).

For soil factors, geostatistical parameters showed greater data dispersion and little spatial dependence (Table 3). The adjusted models did not represent adequately semi-variance contained in the semivariogram, resulting in very low coefficients of determination. Generally, geostatistical results obtained on soil factors were not very useful for interpretation. It was considered that the number of soil samples used was not sufficient to properly express spatial dependency. A greater quantity of sample points would enable the calculation of semi-variance among closer neighboring points, better characterizing their geostatistical performance (DELCOURT et al., 1996).

Because spatial dependence was not obtained for yield, it was chosen to interpolate data by the inverse distance method (Figure 3). The yield map showed great spatial variability in the orchard. It can be observed a low yield area on the right portion of the map occupying a significant area of the field. This region suggests the necessity of differentiated 
management interventions within a field. The variability found also shows how a management system based on uniform applications could provoke errors on agronomic prescriptions and on decision making. Schueller et al. (1999), Tumbo et al. (2002) and Molin and Mascharin (2007) also observed yield variations by using maps generated on manual harvests. They showed the importance of management strategies that consider such variability.

It was noticed that the method used was successful in generating the map with a good detail level and it interfered little in the existing harvest procedure. The georeferencing of bags was the only step in the field that differed from the conventional harvest methods. According to Ampatzidis et al. (2009), making yield maps in hand harvested orchards should not use processes different from the harvest system itself and should be made using direct measurements and not by fruit sampling. The authors also emphasized that ideally the mapping system should allow harvest tracking, associating each tree to the fruits harvested and the harvesters.

The georeferenced gaps and the grid used to calculate gap density are shown in Figure 4 (left). Interpolation by kriging of these data generated the gap density map surface (Figure 4, right). There were few or no gaps in certain regions, but there were also large areas with a fairly high number of gaps, over 100 per hectare, that might even prevent production in these areas. It was also observed that areas with high gap density overlapped areas of low yield, showing the impact of disease incidence on crop yield. This finding shows that application technologies based on presence sensors and canopy volume that automatically avoids application of inputs on plant gaps (DWORAK et al. 2011), are of great importance to improve crop efficiency on orchards with high tree gap density.

Data from the two maps were compared in a correlation graph to ascertain the influence of gap occurrence on orchard yield (Figure 5). Although the linear equation did not presented a very expressive angular coefficient, negative influence of gap density on yield was observed. The 0.64 coefficient of correlation (R) was statistically significant with $95 \%$ probability.

TABLE 1- Fruit production in a Valencia orange orchard made by two measurement methods.

\begin{tabular}{|c|c|c|c|}
\hline Fruit Mass $\left({ }^{1}\right)$ & Load Cell & Estimate $\left({ }^{2}\right)$ & Difference \\
\hline Arithmetic average & 559.24 & 549.48 & -9.75 \\
\hline Sum & 69,346 & 68,136 & $-1,210$ \\
\hline $\mathrm{CV} \%$ & 13.09 & 12.62 & \\
\hline
\end{tabular}

${ }^{1}$ Determination for 293 bags assessed. ${ }^{2}$ Estimative realized by the harvest team leader.

TABLE 2- Descriptive statistics of yield data, gap density and chemical analyses of soil samples.

\begin{tabular}{|c|c|c|c|c|c|c|c|}
\hline \multicolumn{2}{|c|}{ Descriptive parameters } & Average $^{(1)}$ & Standard Deviation & Variance & Min. & Max. & Count \\
\hline \multicolumn{2}{|c|}{ Yield $\left(\mathrm{t} \mathrm{ha}^{-1}\right)$} & 25.56 & 14.58 & 212.66 & 2.58 & 154.02 & 947.00 \\
\hline \multicolumn{2}{|c|}{ Gap density $\left(\right.$ gaps ha $\left.^{-1}\right)$} & 47.76 & 53.18 & 2827.85 & 0.00 & 225.56 & 543.00 \\
\hline \multirow{2}{*}{$\mathrm{pH} \mathrm{CaCl}{ }_{2}$} & Canopy projection & $4.68 b$ & 0.56 & 0.31 & 3.90 & 7.00 & 24.00 \\
\hline & Row center & $5.34 \mathrm{a}$ & 0.54 & 0.29 & 4.60 & 6.80 & 24.00 \\
\hline \multirow{2}{*}{$\mathrm{MO}, \mathrm{mg} \mathrm{dm}^{-3}$} & Canopy projection & $16.79 \mathrm{a}$ & 1.50 & 2.26 & 14.00 & 20.00 & 24.00 \\
\hline & Row center & $15.58 \mathrm{a}$ & 2,36 & 5.56 & 12.00 & 20.00 & 24.00 \\
\hline \multirow{2}{*}{ P-resin, $\mathrm{mg} \mathrm{dm}^{-3}$} & Canopy projection & $52.13 \mathrm{a}$ & 14.98 & 224.29 & 11.00 & 76.00 & 24.00 \\
\hline & Row center & $13.39 \mathrm{~b}$ & 7.50 & 56.25 & 7.00 & 42.00 & 24.00 \\
\hline \multirow{2}{*}{$\mathrm{K}, \mathrm{mmol}_{\mathrm{c}} \mathrm{dm}^{-3}$} & Canopy projection & $1.46 \mathrm{a}$ & 0.39 & 0.16 & 0.30 & 2.10 & 24.00 \\
\hline & Row center & $0.73 b$ & 0.79 & 0.63 & 0.30 & 4.20 & 24.00 \\
\hline \multirow{2}{*}{$\mathrm{Ca}, \mathrm{mmol}_{\mathrm{c}} \mathrm{dm}^{-3}$} & Canopy projection & $13.29 \mathrm{~b}$ & 2.37 & 5.61 & 8.00 & 17.00 & 24.00 \\
\hline & Row center & $17.00 \mathrm{a}$ & 2.77 & 7.65 & 11.00 & 23.00 & 24.00 \\
\hline \multirow{2}{*}{$\mathrm{Mg}, \mathrm{mmol}_{\mathrm{c}} \mathrm{dm}^{-3}$} & Canopy projection & $3.67 \mathrm{~b}$ & 0.87 & 0.75 & 2.00 & 5.00 & 24.00 \\
\hline & Row center & $5.92 \mathrm{a}$ & 1.84 & 3.38 & 3.00 & 11.00 & 24.00 \\
\hline \multirow{2}{*}{$\mathrm{Al}, \mathrm{mmol}_{\mathrm{c}} \mathrm{dm}^{-3}$} & Canopy projection & $1.38 \mathrm{a}$ & 1.01 & 1.03 & 0.00 & 5.00 & 24.00 \\
\hline & Row center & $0.08 \mathrm{~b}$ & 0.28 & 0.08 & 0.00 & 1.00 & 24.00 \\
\hline \multirow{2}{*}{ CTC, $\mathrm{mmol}_{\mathrm{c}} \mathrm{dm}^{-3}$} & Canopy projection & $43.79 \mathrm{a}$ & 4.55 & 20.69 & 32.00 & 50.00 & 24.00 \\
\hline & Row center & $39.79 b$ & 3.61 & 13.04 & 33.00 & 48.00 & 24.00 \\
\hline \multirow{2}{*}{ Base saturation, $\%$} & Canopy projection & $42.79 \mathrm{~b}$ & 9.63 & 92.78 & 23.00 & 72.00 & 24.00 \\
\hline & Row center & $59.63 \mathrm{a}$ & 8.70 & 75.72 & 41.00 & 79.00 & 24.00 \\
\hline
\end{tabular}

${ }^{1}$ Means followed by different letters in the column and for different attributes of soil chemical analysis are different by the $t$ test of paired means (Prob. $<0.05)$. 
TABLE 3- Geostatistical parameters of yield data, gap density and soil chemical aspects obtained in a Valencia orange orchard.

\begin{tabular}{|c|c|c|c|c|c|c|c|}
\hline \multicolumn{2}{|c|}{ Descriptive parameters } & $\mathrm{CO}$ & $\mathrm{C} 1$ & A1 & $\mathrm{k}^{*}$ & Model & $\mathrm{R}^{2}$ \\
\hline \multicolumn{2}{|c|}{ Yield (t ha $\left.{ }^{-1}\right)$} & 186.90 & 82.37 & 688.20 & 0.69 & exponential & 0.83 \\
\hline \multicolumn{2}{|c|}{ Gap density (gaps ha ${ }^{-1}$ ) } & $2,022.70$ & $2,136.80$ & 153.50 & 0.49 & exponential & 0.94 \\
\hline \multirow{2}{*}{$\mathrm{pH} \mathrm{CaCl}{ }_{2}$} & Canopy projection & 0.00 & 0.34 & 118.10 & 0.00 & spherical & 0.05 \\
\hline & Row center & 0.00 & 0.31 & 43.59 & 0.00 & exponential & 0.14 \\
\hline \multirow{2}{*}{$\mathrm{MO}, \mathrm{mg} \mathrm{dm}^{-3}$} & Canopy projection & 1.19 & 1.18 & 311.83 & 0.50 & spherical & 0.13 \\
\hline & Row center & 3.49 & 3.79 & 300.05 & 0.48 & exponential & 0.12 \\
\hline \multirow{2}{*}{ P-resin, $\mathrm{mg} \mathrm{dm}^{-3}$} & Canopy projection & 0.00 & 250.08 & 101.35 & 0.00 & spherical & 0.01 \\
\hline & Row center & 0.00 & 62.16 & 128.45 & 0.00 & spherical & 0.01 \\
\hline \multirow{2}{*}{$\mathrm{K}, \mathrm{mmol}_{\mathrm{c}} \mathrm{dm}^{-3}$} & Canopy projection & 0.00 & 0.18 & 110.91 & 0.00 & spherical & 0.00 \\
\hline & Row center & 0.54 & 0.08 & 300.05 & 0.87 & spherical & 0.08 \\
\hline \multirow{2}{*}{$\mathrm{Ca}, \mathrm{mmol}_{\mathrm{c}} \mathrm{dm}^{-3}$} & Canopy projection & 5.32 & 0.51 & 1.68 & 0.91 & exponential & 0.00 \\
\hline & Row center & 7.23 & 0.04 & 300.05 & 0.99 & exponential & 0.00 \\
\hline \multirow{2}{*}{$\mathrm{Mg}, \mathrm{mmol}_{\mathrm{c}} \mathrm{dm}^{-3}$} & Canopy projection & 0.09 & 0.71 & 140.55 & 0.11 & spherical & 0.17 \\
\hline & Row center & 0.23 & 3.17 & 101.96 & 0.07 & spherical & 0.06 \\
\hline \multirow{2}{*}{$\mathrm{Al}, \mathrm{mmol}_{\mathrm{c}} \mathrm{dm}^{-3}$} & Canopy projection & 1.03 & 0.03 & 183.65 & 0.97 & exponential & 0.06 \\
\hline & Row center & 0.00 & 0.08 & 126.59 & 0.00 & exponential & 0.10 \\
\hline \multirow{2}{*}{ CTC, $\mathrm{mmol}_{\mathrm{c}} \mathrm{dm}^{-3}$} & Canopy projection & 0.00 & 2.58 & 110.01 & 0.00 & spherical & 0.10 \\
\hline & Row center & 0.00 & 13.02 & 28.57 & 0.00 & exponential & 0.09 \\
\hline
\end{tabular}

$* \mathrm{k}$ ratio $=\mathrm{C} 0 / \mathrm{C} 0+\mathrm{C} 1$

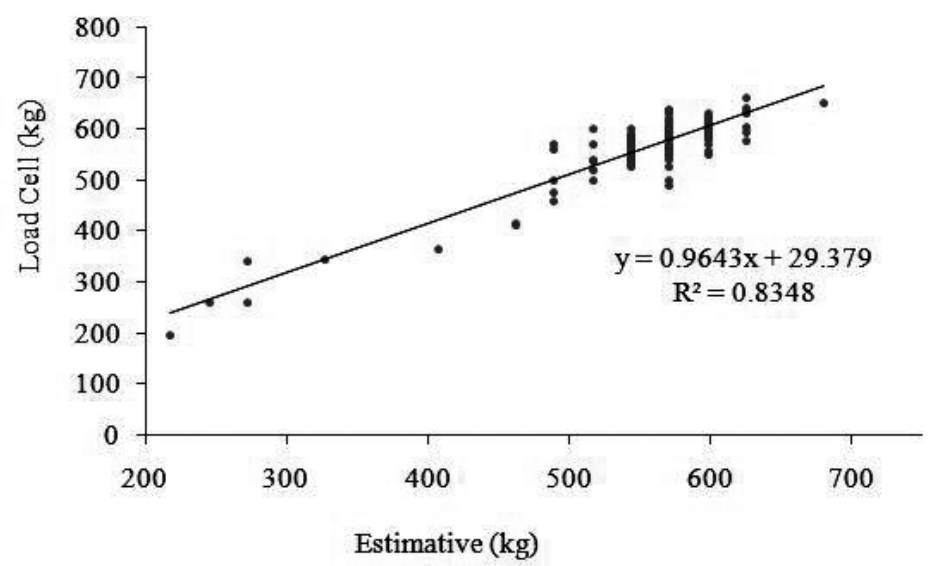

FIGURE 1- Relation of the estimated bags mass compared to the real mass obtained with the load cell. 

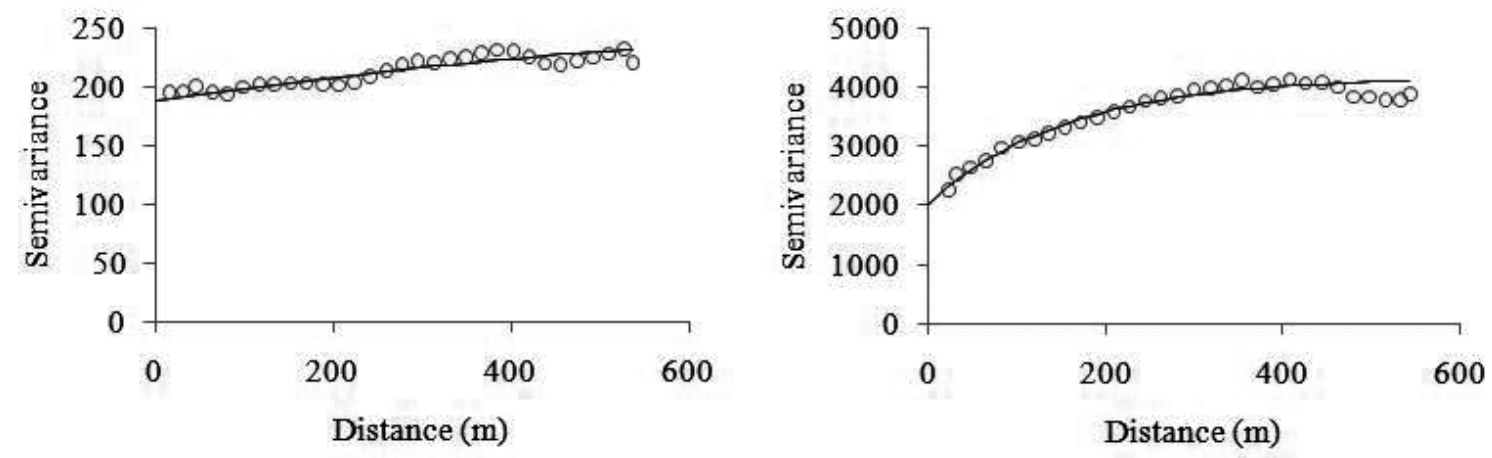

FIGURE 2- Semivariogram of yield and gap density points obtained in Valencia orange orchard.

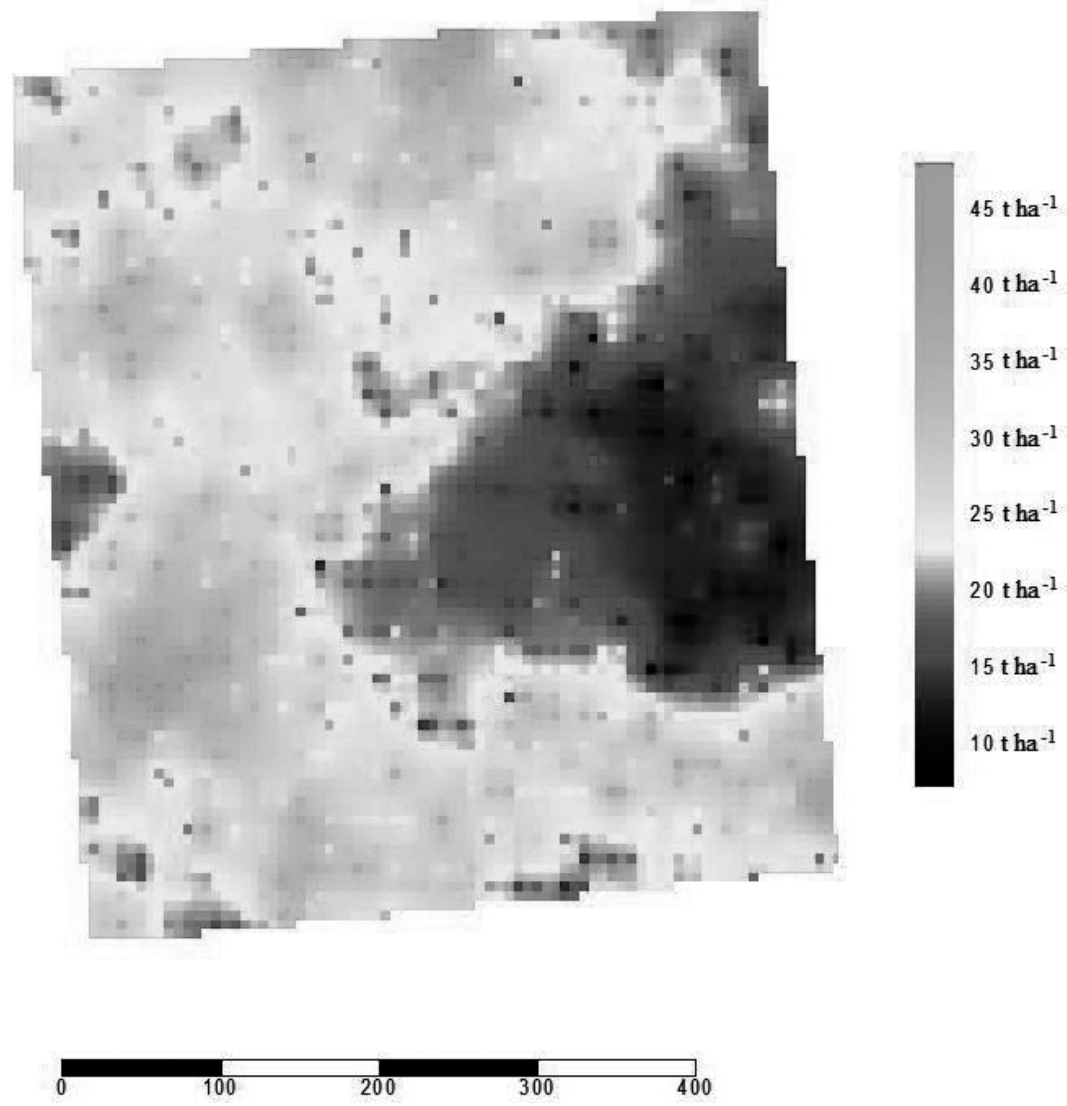

FIGURE 3- Yield map obtained in a Valencia orange orchard. 

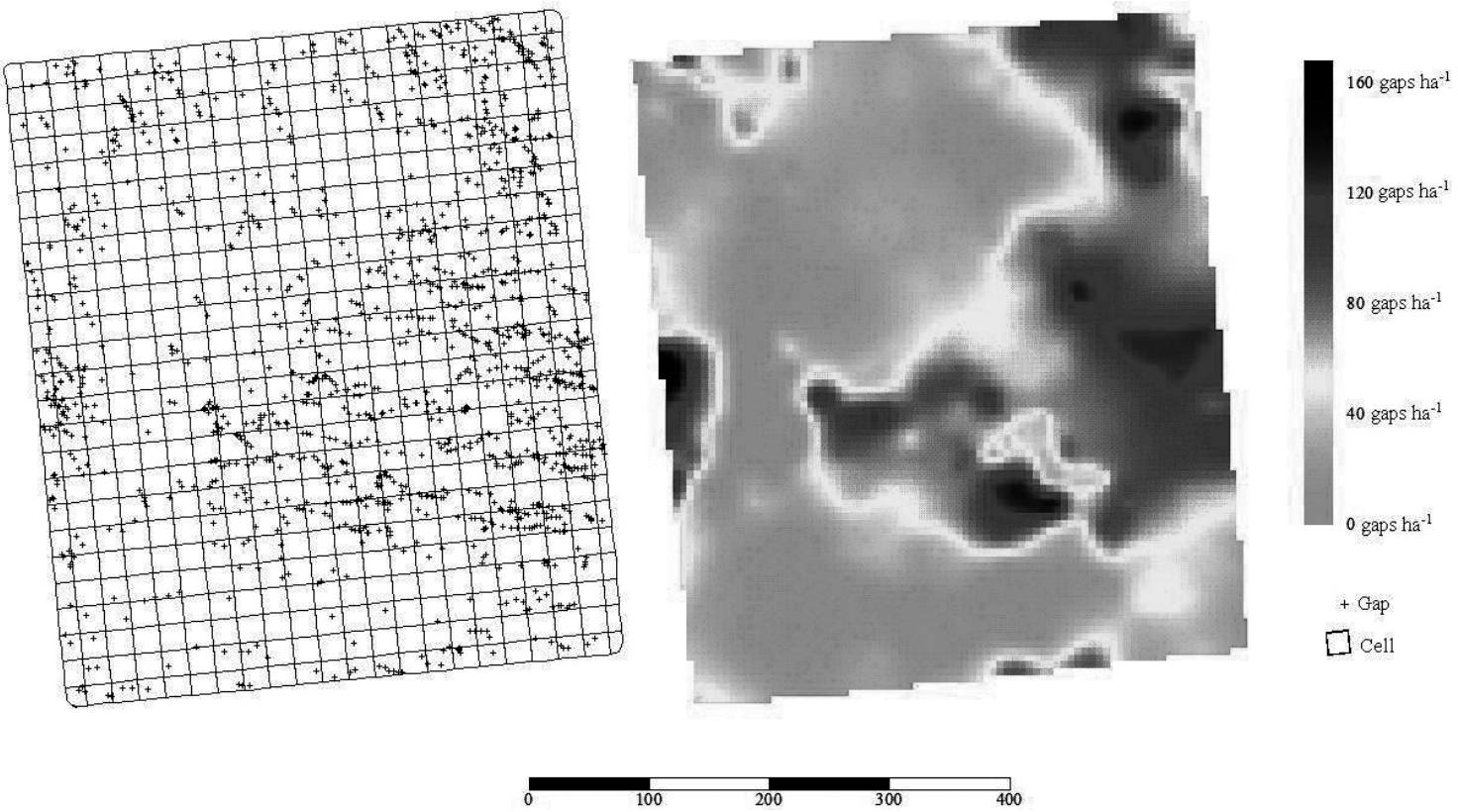

FIGURE 4- Georeferenced gaps and grid to calculate gap density (left); gap density map in a Valencia orange orchard (right).

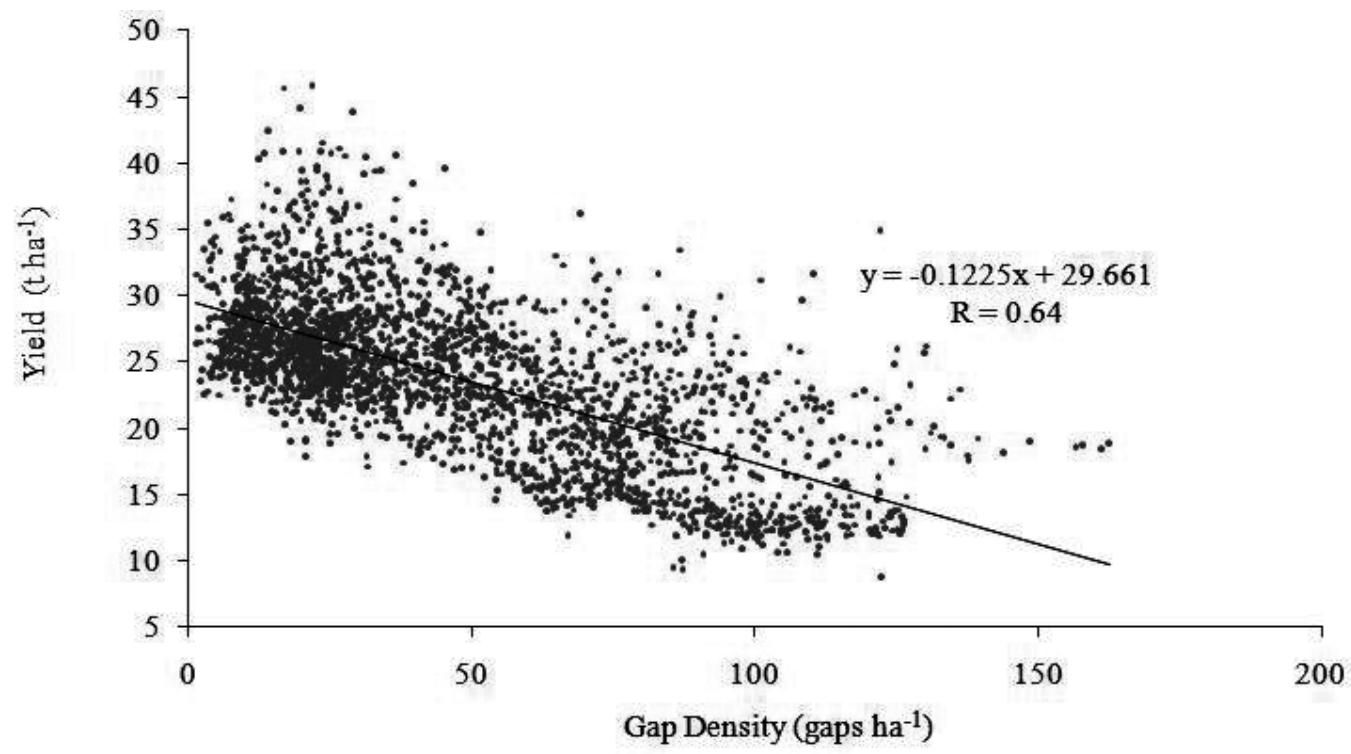

FIGURE 5- Correlation between yield and gap density of plants in a Valencia orange orchard. 


\section{CONCLUSSION}

1-Through a spatial data survey, mapping techniques, statistical and geostatistical analysis, this study has shown that fruit yield, soil chemical parameters and disease occurrence presented significant spatial variability within a 26 ha orange orchard. The spatial vision of these factors reveals the need to adopt site specific management practices that acts on the causes of variability. The mapping techniques were successful on representing variability and helped the understanding of cause/ effect relationship among the parameters assessed.

2-The method used to generate yield maps can uncover yield spatial variability and it is easily adapted to hand-harvest systems. Georeferencing gaps and the generation of the interpolated map surface showed the disease distribution in the field and its impact on yield.

3-Soil chemical fertility also demonstrated variability, especially on elements frequently managed as phosphorus, potassium, calcium and magnesium. Mapping soil fertility on this study demanded a number of point samples greater than 1 per hectare.

4-Local variability was also found between sampling point regions. This suggests that sampling location must be considered to better represent the soil fertility.

\section{REFERENCES}

AMPATZIDIS, Y. G.; VOUGIOUKAS, S. G.; BOCHTIS, D. D.; TSATSARELIS, C. A. A yield mapping system for hand-harvested fruits based on RFID and GPS location technologies: field testing. Precision Agriculture, Dordrecht, v.10, n.1, p.6372, 2009.

BOVÉ, J.M. Huanglongbing: a destructive, newlyemerging, century-old disease of citrus. Journal of Plant Pathology, Pisa, v.88, n.1, p.7-37, 2006.

CANTARELLA, H.; MATTOS Jr., D.; QUAGGIO, J.A.; RIGOLIN, A. T. Fruit yield of Valencia sweet orange fertilized with different $\mathrm{N}$ sources and the loss of applied N. Nutrient Cycling in Agroecosystems, Dordrecht, v. 67, n. 3, p. 205-213, 2003.

CARLOS, E.F.; LEMOS, E.G.M.; DONADIO, L.C. O Declínio dos citros. Laranja, Cordeirópolis, v.21, n.1, p.175-203, 2000.
COSTA, M. G.; BARBOSA, J. C.; TAMAMOTO, P. T.; LEAL, R. M. Spatial distribution of Diaphorina citri Kuwayama (Hemiptera: Psyllidae) in citrus orchards. Scientia Agrícola, Piracicaba, v. 67, n.5, p.546-554, 2010.

DELCOURT,H.;DARIUS,P.L.;BAERDEMAEKER, J. D. The spatial variability of some aspects of topsoil fertility in two Belgian fields. Computers and Electronics in Agriculture, Oxford, v.14, p.179176, 1996.

DWORAK, V.; SELBECK, J.; EHLERT, D. Ranging sensors for vehicle-based measurement of crop stand and orchard parameters: a review. Transactions of the ASABE, St. Joseph, v.54, n.4, p.1497-1510, 2011.

FAO. Food and Agriculture Organization. FAOSTAT data 2010. Disponível em: $<$ http://faostat.fao.org/> Acesso em: 18 jun. 2012.

FARIAS, P.R.S.; NOCITI, L.A.S.; BARBOSA, J.C.; PERECIN, D. Agricultura de precisão: mapeamento da produtividade em pomares cítricos usando geoestatística. Revista Brasileira de Fruticultura, Jaboticabal, v.25, n.2, p.235-41, 2003.

ISGIN, T.; BILGIC, A.; FORSTER, D. L.; BATTE, M. T. Using count data models to determine the factors affecting farmer's quantity decisions of precision farming technology adoption. Computers and Electronics in Agriculture, Oxford, v.62, n.2, p.231-242, 2008.

LAMB, D. W.; FRAZIER, P.; ADAMS, P. Improving pathways to adoption: Putting the right P's in precision agriculture. Computers and Electronics in Agriculture, Oxford, v.61, n.1, p.4-9, 2007.

LEAL, M. R.; BARBOSA, J. C.; COSTA, M. G.; BELASQUE JR., J.; YAMAMOTO, P. T.; DRAGONE, J. Distribuição espacial de huanglongbing (greening) em citros utilizando a geoestatística. Revista Brasileira de Fruticultura, Jaboticabal, v.32, n.3, p.808-818, 2010.

MARUYAMA, W. I.; BARBOSA, J. C.; TOSCANO, L. C. Distribuição espacial de Oncometopia facialis (Signoret) (Hemiptera: Cicadellidae) em pomar cítrico. Neotropical Entomology, Londrina, v.35, n.1, p.093-100, 2006. 
MOLIN, J. P.; MASCHARIN, L. S. Colheita de citros e obtenção de dados para mapeamento da produtividade. Engenharia Agrícola, Jaboticabal, v.27, n.1, p.259-266, 2007.

OKAMOTO, H.; LEE, W. S. Green citrus detection using hyperspectral imaging. Computers and Electronics in Agriculture, Oxford, v.66, n.2, p.201-208, 2009.

OLIVEIRA, P. C. G.; FARIAS, P. R. S.; LIMA, H. V.; FERNANDES, A. R.; OLIVEIRA, F. A.; PITA, J. D. Variabilidade espacial de propriedades químicas do solo e da produtividade de citros na Amazônia oriental. Revista Brasileira de Engenharia Agrícola e Ambiental, Campina Grande, v.13, n.6, p.708-715, 2009.

PARISE, F. J. O.; VETTORAZZI, C. A. Análise de dados de produção em um pomar jovem de laranjeiras hamlin: II. Classificação de dados espaço-temporais. Revista Brasileira de Fruticultura, Jaboticabal, v.27, n.1, p.48-51, 2005.

QUAGGIO, J. A.; TEÓFILO SOBRINHO, J.; DECHEN, A. R. Response to liming of Valencia orange tree on Rangpur lime: Effects of soil acity on plant growth and yield. In: INTERNATIONAL CITRUS CONGRESS, 1992, Valencia. Proceedings... v. 2, p. 628-632.

QUAGGIO, J.A.; MATTOS Jr., D.; CANTARELLA, H.; STUCHI, E. S.; SEMPIONATO, O. R.; Sweet orange trees grafted on selected rootstocks fertilized with nitrogen, phosphorus and potassium. Pesquisa Agropecuária Brasileira, Brasília, v.39, n.1, p.5560, 2004.

RAIJ, B. van; ANDRADE, J.C.; CANTARELLA, H.; QUAGGIO, J.A. Análise química para avaliação da fertilidade de solos tropicais. Campinas: Instituto Agronômico, 2001. p.285.

SANKARAM, S.; MISHRA, A.; EHSANI, R.; DAVIS, C. A review of advanced techniques for detecting plant diseases. Computers and Electronics in Agriculture, Oxford, v.72, n.1, p.113, 2010.

SCHUELLER, J.K.; WHITNEY, J.D.; WHEATON, T.A.; MILLER, W.M.; TURNER, A.E. Low-cost automatic yield mapping in hand-harvested citrus. Computers and Electronics in Agriculture, Oxford, v.23, n.2, p.145-53, 1999.
SCHUMANN, A. W.; MILLER, W. M.; ZAMAN, Q. U.; HOSTLER, K. H.; BUCHANON, S.; CUGATI, $\mathrm{S}$. Variable rate granular fertilization of citrus groves: Spreader performance with singles-tree prescription zones. Applied Engineering in Agriculture, St. Joseph, v.22, n.1, p. 19-24, 2006.

SEVIER, B. J.; LEE, W. S. Precision agriculture in citrus: A probit model analysis for technology adoption. In: ASAE/CSAE ANNUAL INTERNATIONAL MEETING, 2004, Ottawa. Proceedings ...

SIQUEIRA, D. S.; MARQUES Jr., J.; PEREIRA, G.T. The use of landforms to predict the variability of soil and orange attributes. Geoderma, Amsterdam, v.155, n.1, p.55-66, 2010.

TUCKER, D.P.H., LEE, R.F., TIMMER, L.W., ALBRIGO, L.G., BRLANSKY, R.H. Experimental transmission of citrus blight. Plant Disease, St. Paul, v.68, n.11, p.979-980, 1984.

TUMBO, S. D.; WHITNEY, J. D.; MILLER, W. M., WHEATON, T. A. Development and testing of a citrus yield monitor. Applied Engineering in Agriculture, St. Joseph, v.18, n.4, p. 399-403, 2002.

WHITNEY, J. D.; MILLER, W. M.; WHEATON, T. A.; SALYANI, M.; SCHUELLER, J. K. Precision farming applications in Florida citrus. Applied Engineering in Agriculture, St. Joseph, v.15, n.5, p. 399-403, 1999.

ZAMAN, Q. U.; SCHUMANN, A. W.; HOSTLER, H. K. Estimation of citrus fruit yield using ultrasonically-sensed tree size. Applied Engineering in Agriculture, St. Joseph, v.22, n. 1, p. 39-44, 2006.

ZAMAN, Q. U.; SCHUMANN, A. W. Nutrient management zones for citrus based on variation in soil properties and tree performance. Precision Agriculture, Dordrecht, v.7, n.1, p.45-63, 2006. 